\title{
Volatile Terpenes and Brain Function: Investigation of the Cognitive and Mood Effects of Mentha $\times$ Piperita $L$. Essential Oil with In Vitro Properties Relevant to Central Nervous System Function
}

\author{
David Kennedy ${ }^{1, *}$, Edward Okello ${ }^{2}$, Paul Chazot ${ }^{3}$, Melanie-Jayne Howes ${ }^{4}$, \\ Samuel Ohiomokhare ${ }^{3}$, Philippa Jackson ${ }^{1}$ (), Crystal Haskell-Ramsay ${ }^{1}$ (), Julie Khan ${ }^{1}$, \\ Joanne Forster ${ }^{1}$ and Emma Wightman ${ }^{1}$ \\ 1 Brain, Performance and Nutrition Research Centre, Northumbria University, \\ Newcastle upon Tyne NE1 8ST, UK; philippa.jackson@northumbria.ac.uk (P.J.); \\ crystal.haskell-ramsay@northumbria.ac.uk (C.H.-R.); julie.khan@northumbria.ac.uk (J.K.); \\ jo.forster@northumbria.ac.uk (J.F.); emma.l.wightman@northumbria.ac.uk (E.W.) \\ 2 Human Nutrition Research Centre, Institute of Cellular Medicine, Medical School, Newcastle University, \\ Newcastle upon Tyne NE2 4HH, UK; edward.okello@ncl.ac.uk \\ 3 Department of Biosciences, Durham University, Durham DH1 3LE, UK; paul.chazot@durham.ac.uk (P.C.); \\ samuel.ohiomokhare@durham.ac.uk (S.O.) \\ 4 Natural Capital and Plant Health Department, Royal Botanic Gardens Kew, Jodrell Laboratory, \\ Richmond TW9 3AB, UK; M.Howes@kew.org \\ * Correspondence: david.kennedy@northumbria.ac.uk; Tel.: +44-0191-2437-720
}

Received: 12 July 2018; Accepted: 2 August 2018; Published: 7 August 2018

\begin{abstract}
Background: Extracts of several members of the monoterpene-rich Lamiaceae sub-family Nepetoideae, including those from the Salvia (sage), Melissa (Lemon balm) and Rosmarinus (rosemary) genera, evince cognitive and mood effects in humans that are potentially related to their effects on cholinergic and GABAergic neurotransmission. To date, despite promising in vitro properties, the cognitive and mood effects of the closely related Mentha spicata (spearmint) and Mentha piperita (peppermint) remain unexplored. This study therefore assessed the human cognitive/mood effects of the M. spicata/piperita essential oil with the most promising, brain-relevant in vitro properties according to pre-trial in vitro screening. Design: Organic spearmint and peppermint (Mentha spicata/piperita) essential oils were pre-screened for neurotransmitter receptor binding and acetylcholinesterase (AChE) inhibition. In a double-blind, placebo-controlled, balanced cross-over study, 24 participants (mean age 25.2 years) consumed single doses of encapsulated placebo and $50 \mu \mathrm{L}$ and $100 \mu \mathrm{L}$ of the most promising essential oil (peppermint with nicotinic/GABAA receptor binding and $\mathrm{AChE}$ inhibitory properties, that increased calcium influx in a CAD cell neuronal model). Psychological functioning was assessed with mood scales and a range of standardised, cognitively demanding tasks pre-dose and at 1, 3 and $6 \mathrm{~h}$ post-dose. Results: The highest $(100 \mu \mathrm{L})$ dose of essential oil improved performance on the cognitively demanding Rapid Visual Information Processing task (RVIP) at $1 \mathrm{~h}$ and $3 \mathrm{~h}$ post-dose and both doses attenuated fatigue and improved performance of the Serial $3 \mathrm{~s}$ subtraction task at $3 \mathrm{~h}$ post-dose. Conclusion: Peppermint (Mentha piperita) essential oil with high levels of menthol/menthone and characteristic in vitro cholinergic inhibitory, calcium regulatory and $\mathrm{GABA}_{\mathrm{A}} /$ nicotinic receptor binding properties, beneficially modulated performance on demanding cognitive tasks and attenuated the increase in mental fatigue associated with extended cognitive task performance in healthy adults. Future investigations should consider investigating higher doses.
\end{abstract}

Keywords: mint; Mentha; terpenes; cognition 


\section{Introduction}

The Lamiaceae, or mint family of flowering plants, comprises over 7000 plant species. Its largest sub-family, the Nepetoideae, comprises numerous species, including those in the genera Origanum (oregano), Ocimum (basil), Thymus (thyme), Salvia (sage), Lavandula (lavender), Melissa (Lemon balm), Rosmarinus (rosemary) and Mentha (mint; e.g., spearmint (M. spicata L.) and peppermint (M. piperita L.)). Plants in these genera typically synthesize high concentrations of volatile and pleasantly odorous mono-/sesqui-terpenes which include menthol, menthone, menthofuran, isomenthone, $(E)$-caryophyllene, 1,8-cineole, linalool, limonene, carvone, pulegone and $\alpha$-terpineol [1]. Consequently, this plant group is a particularly rich source of essential oils (usually a steam-distilled liquid containing volatile aroma compounds). Evidence suggests that the psychotropic properties of the above plants reside in these volatile constituents and, as a consequence, the essential oils they produce may also exert neurocognitive effects.

As an example, in vitro studies show that Lemon balm (Melissa officinalis L.) essential oil has an affinity for gamma-aminobutyric acid $A\left(G A B A_{A}\right)$ receptors and exert a net depressant effect on neuronal activity (commensurate with anxiolytic effects) as assessed by patch clamp electrophysiology [2]. Several randomised, double-blind, placebo-controlled, balanced-crossover trials have also demonstrated anxiolytic-like effects in humans following single doses of ethanolic extract or dried leaf powder of Lemon balm [3-5]; whilst chemically-characterised and combined ethanolic extracts of sage (S. officinalis L.), rosemary (Rosmarinus officinalis L.; accepted name: Salvia rosmarinus Schleid.) and Lemon balm improved memory in a randomised, double-blind, placebo-controlled pilot trial [6]. Similarly, single doses of dried leaf [7] and an ethanolic extract [8] of sage; containing a wide spectrum of phytochemicals, have both been shown to significantly improve mood and cognitive function. However, the most recent of these studies confirmed that the psychoactive properties of sage were evident following an essential oil composed exclusively of monoterpenes. This and other essential oils, as well as a wide range of sage extracts, also exhibited in vitro cholinesterase inhibiting properties [7,9-16], that were potentially predicated on synergies between the monoterpene components $[12,13]$.

To date, with the exception of consistent evidence of cognitive/mood effects for sage, Lemon balm and rosemary, the psychoactive potential of many of the remaining edible aromatic Lamiaceae species remain under-investigated. One of the most promising groups of plants in this respect is the Mentha genus and, in particular, Mentha spicata (spearmint) and Mentha $\times$ piperita (peppermint); which are widely used as food components, flavourings and for their medicinal properties. The latter include uses as antispasmodics [17], anti-emetics [18] and treatments for irritable bowel syndrome and as topical analgesics [19].

Members of the genus typically express several monoterpenes that provide their "minty" flavour and odour; most notably menthol, menthone, limonene, piperitone, carvone and their derivatives, alongside the more typical monoterpenes expressed by related genera $[20,21]$. These monoterpene components may exert a number of effects directly relevant to brain function. These include: cholinesterase inhibition activity by essential oils [20,22,23]; allosteric serotonin 5-hydroxytryptamine-3 (5- $\left.\mathrm{HT}_{3}\right)$ receptor modulation by menthol alone and peppermint oil [24]; negative allosteric modulation of $\mathrm{GABA}_{\mathrm{A}}$ receptors by carvone [25]; and positive allosteric modulation of $\mathrm{GABA}_{\mathrm{A}}$ receptors by menthol [26-28]. Menthol also exerts several other unique effects which may be tangentially relevant to central nervous system (CNS) functioning; including the allosteric activation of glycine receptors [26] and modulation of the function of transient receptor potential cation channel subfamily M member 8 (TRPM8) "cold menthol" receptors [29] and kappa opioid receptors [30].

In terms of the effects of these CNS interactions, investigations utilizing animal models have observed increased ambulatory behaviour [31], improved memory [32] and anxiolytic effects which are potentially driven by modulation of serotonergic or dopaminergic function [33]. Currently, only one controlled trial has investigated the brain function effects of Mentha species in humans. Here promising effects were observed on quality of working memory and spatial working memory as well as improved sleep onset and vigour, alertness and overall mood in a group of 50-70 years olds 
following 90 days supplementation with $600 \mathrm{mg}$ and $900 \mathrm{mg}$ of an aqueous extract of Mentha spicata (spearmint) that contained the phenolic constituents but not the terpene constituents of the plant material [34]. The current study extends this research by investigating the cognitive and mood effects of oral administration of mint essential oil comprised of the volatile terpene phytochemical constituents of a Mentha plant, in healthy, young humans. A preliminary in vitro analysis assessing the acetylcholinesterase $(\mathrm{AChE})$ inhibitory properties and $\mathrm{GABA}_{\mathrm{A}}$, glutamate $\mathrm{N}$-Methyl-D-aspartic acid (NMDA) and nicotinic receptor binding properties of a range of organic M. spicata and M. piperita essential oils was conducted in order to select a treatment liable to exert CNS effects relevant to cognitive function and mood.

\section{Pre-Trial in Vitro Screening of Essential Oils}

\subsection{Methods}

\subsubsection{Receptor Binding}

Six organic Mentha spicata and M. piperita essential oils were investigated in radioligand competition binding assays using a range of ligand-gated ion channel radioligands targeting the $\mathrm{GABA}_{\mathrm{A}}$, neuronal nicotinic and NMDA glutamate receptors.

An initial screen was performed at $0.1 \mathrm{mg} / \mathrm{mL}$ for each mint essential oil versus $\left[{ }^{3} \mathrm{H}\right]$ flunitrazepam, $\left[{ }^{3} \mathrm{H}\right]$ nicotine and $\left[{ }^{3} \mathrm{H}\right]$ MK801 (as described in [35]).

A series of dose-response competition binding experiments were then performed with the essential oil that exhibited the most interesting pattern of receptor binding (test concentrations, $0.0001-1 \mathrm{mg} / \mathrm{mL}$ ) using $\left[{ }^{3} \mathrm{H}\right]$ flunitrazepam, $\left[{ }^{3} \mathrm{H}\right] \mathrm{MK}-801$ and $\left[{ }^{3} \mathrm{H}\right]$ nicotine, using well-washed adult rat forebrain membranes [35].

The data were fitted to a non-linear regression dose response curve with variable slope and apparent $\mathrm{pIC}_{50}$ values determined using GraphPad Prism 4 . Apparent $\mathrm{pIC}_{50}$ values $\mathrm{Vs}\left[{ }^{3} \mathrm{H}\right]$ flunitrazepam and $\left[{ }^{3} \mathrm{H}\right]$ nicotine were $1.79 \pm 0.11$ and $1.88 \pm 0.24$, respectively. No significant effect was seen on $\left[{ }^{3} \mathrm{H}\right]$ MK801 binding up to a concentration of $1 \mathrm{mg} / \mathrm{mL}$ ( $n=3$ independent experiments performed in triplicate)

\subsubsection{AChE Inhibition}

The ability of the essential oils to inhibit acetylcholinesterase (AChE) from Electrophorus electricus was assessed using the colorimetric method of Ellman [36] as described by Okello et al. [37].

\subsubsection{GC-MS Analysis}

The GC-MS analyses were performed using an Agilent 7890A GC coupled to an Agilent 5975C MS. The oils were analysed using the GC-MS method described previously [35]. In summary, chromatography was performed using a $30 \mathrm{~m} \times 0.25 \mathrm{~mm}$ ID $\times 0.25 \mu \mathrm{m}$ DB- $5 \mathrm{MS}$ column (J \& W Scientific Inc., Rancho Cordova, CA, USA) using a temperature programme of $40-300{ }^{\circ} \mathrm{C}$ at a rate of $3{ }^{\circ} \mathrm{C} / \mathrm{min}$. The carrier gas was helium at a flow rate of $1 \mathrm{~mL} / \mathrm{min}$ and the injection volume was $1 \mu \mathrm{L}$ (split 1:10) at $220^{\circ} \mathrm{C}$, via an autosampler. Detection was by MS, fitted with electrospray ionisation source operated at $70 \mathrm{eV}$, with a source temperature of $180{ }^{\circ} \mathrm{C}$; mass spectra were recorded in the range $\mathrm{m} / \mathrm{z} 38-600$. Compounds were identified by comparing retention indices and/or mass spectra with published data [38,39]. Percentage compositions were calculated by integrating peaks for detected oil constituents in total ion chromatograms.

\subsubsection{Neuronal Calcium Mobilisation}

Menthol, the major constituent of M. piperita oil ( $36 \%$ in this test sample) has been previously shown to stimulate calcium mobilisation in a range of cell types, including neurons [40]. In order to establish the functional neuronal effects of the chosen essential oil neuronal calcium mobilisation was quantified in differentiated CAD cells. 
A $2 \mathrm{mM}$ stock of the Calcium Green ${ }^{\mathrm{TM}}-1 \mathrm{AM}$ (ThermoFisher Scientific, Cramlington, UK) probe was prepared in DMSO (Sigma, Poole, UK); this was stored at $-20{ }^{\circ} \mathrm{C}$ for up to 2 months. On the day of the imaging experiments the probe stock was brought to room temperature and then diluted in HEPES physiological buffer (150 mM NaCl, $1 \mathrm{mM} \mathrm{MgCl}, 10 \mathrm{mM} \mathrm{HEPES,} 2 \mathrm{mM} \mathrm{CaCl} 2,5 \mathrm{mM} \mathrm{KCl})$ to a $1 \mu \mathrm{M}$ solution. The cells were plated in flat bottom $\mu$-dishes $(60 \mu$-Dish, $35 \mathrm{~mm}$, high glass flat bottom, Ibidi $\mathrm{GmbH}$ ). The cells were washed with $1 \mathrm{~mL}$ of physiological buffer and incubated for $40 \mathrm{~min}$ in $1 \mathrm{~mL}$ of the Calcium-Green solution $(1 \mu \mathrm{M})$. After the incubation period, the cells were washed again with the HEPES physiological buffer and maintained in HEPES physiological buffer prior to the imaging experiments. All reagents applied to the clonal cells during the experiments were dissolved in the HEPES physiological buffer.

The incubation period for each treatment was for periods of 250 cycles $(0.63 \mathrm{~s}$ each) before the appliance of the depolarising buffer $(50 \mathrm{mM} \mathrm{KCl})$ and then imaged for a further period of 250 cycles. All the solutions were kept at $37^{\circ} \mathrm{C}$ to avoid any stress on the cells during the sample preparation and the imaging experiment. For the imaging, the Zeiss LSM 850 with an Airyscan microscope was used. The laser used for imaging was set at $514 \mathrm{~nm}$ : 1.1\% (Ch2GaAsp: 524-620). The spectrum window was set between 24,620 and a pin hole of $49 \mu \mathrm{m}$ was used. A size 63 oil lens with an LA of 1.4 was used to capture each image and the time between each frame (time series) was set at zero. The duration for one frame was $633.02 \mathrm{~ms}$. To extract the figures and fluorescence intensities, the Zeiss software was used.

The neuroprotective properties of the selected essential oil, assessed in CAD cell cultures subjected to hydrogen peroxide were also investigated (methods and results in online Supplementary Materials).

\subsection{Results}

The $\mathrm{GABA}_{\mathrm{A}}$, nicotinic and NMDA receptor binding properties, acetylcholinesterase (AChE) inhibition and major terpene constituents of the 6 organic essential oils included in the initial in vitro screening are shown in Table 1. The full GC-MS analysis results for the essential oils can be found in the online supplementary materials (Table S1).

Table 1. Results from the initial screening of essential oils (receptor binding at a concentration of $0.1 \mathrm{mg} / \mathrm{mL}$ ) and major constituents detected in each Mentha species by GC-MS analysis.

\begin{tabular}{|c|c|c|c|c|c|c|}
\hline & \multicolumn{3}{|c|}{ Mentha spicata } & \multicolumn{3}{|c|}{ Mentha $\times$ piperita } \\
\hline $\begin{array}{l}\text { Essential Oil Number } \\
\text { GABA }_{A} \text { receptor }\end{array}$ & 1 & 2 & 3 & 4 & 5 & 6 \\
\hline $\begin{array}{l}\% \text { displacement }\left({ }^{3} \mathrm{H}\right) \\
\text { flunitrazepam }\end{array}$ & $35 \pm 3$ & $25 \pm 2$ & $42 \pm 5$ & $42 \pm 3$ & $25 \pm 2$ & $15 \pm 2$ \\
\hline $\begin{array}{l}\text { Nicotinic receptor } \\
\% \text { displacement }\left({ }^{3} \mathrm{H}\right) \text { nicotine }\end{array}$ & $30 \pm 3$ & $25 \pm 4$ & $21 \pm 8$ & $52 \pm 5$ & $50 \pm 5$ & $49 \pm 1$ \\
\hline $\begin{array}{l}\text { NMDA receptor } \\
\% \text { displacement }\left({ }^{3} \mathrm{H}\right) \mathrm{MK} 801\end{array}$ & $0 \pm 3$ & $0 \pm 2$ & $5 \pm 4$ & $0 \pm 2$ & $10 \pm 3$ & $5 \pm 1$ \\
\hline AChE Inhibition \% & 79.45 & 66.21 & 70.78 & 70.09 & 73.97 & 73.74 \\
\hline \multicolumn{7}{|c|}{ Major constituents detected in each sample by GC-MS } \\
\hline \% Limonene & 20.8 & 20.8 & 18.4 & 2.3 & 2.4 & 2.0 \\
\hline$\%$ Carvone & 61.9 & 57.5 & 58.8 & 0.1 & 0.1 & 0.1 \\
\hline$\%$ Menthone & 0.4 & 1.7 & 0.1 & 24.9 & 24.7 & 24.2 \\
\hline \% Menthol & 0.5 & 2.8 & 0.80 & 36.7 & 32.5 & 34.7 \\
\hline
\end{tabular}

On the basis of high $\mathrm{GABA}_{\mathrm{A}}$ and nicotinic receptor binding and AChE inhibitory properties, essential oil 4 (see Table 1) was taken forward into the dose-response experiments and the investigation of neuronal calcium mobilisation and neuroprotective properties.

In the dose-response competition binding investigation the chosen $M$. piperita essential oil inhibited both $\left[{ }^{3} \mathrm{H}\right]$ nicotine and $\left[{ }^{3} \mathrm{H}\right]$ flunitrazepam binding in a concentration-dependent manner (and with similar apparent $\mathrm{IC}_{50}$ values) with no significant effects on $\left[{ }^{3} \mathrm{H}\right] \mathrm{MK} 801$ binding (see Figure 1.). This was consistent with previous studies focusing on menthol, the major component of M. piperita oil $[41,42]$. 


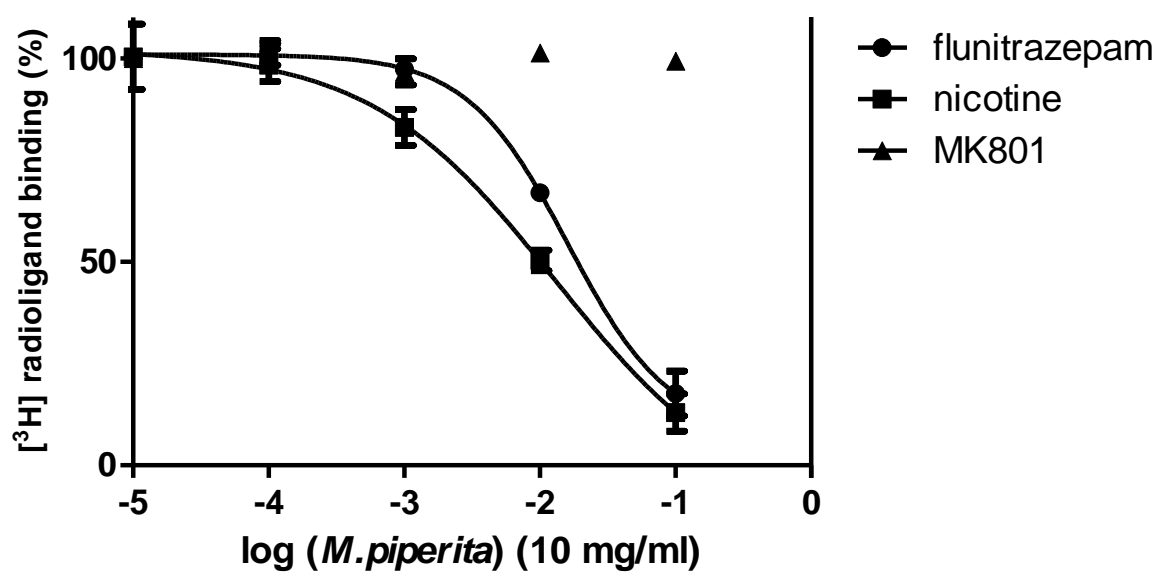

Figure 1. Dose-response radioligand binding properties of $M$. piperita essential oil (sample 4) in adult rat forebrain membranes at concentrations between, 0.000 and $1 \mathrm{mg} / \mathrm{mL}$ using $\left[{ }^{3} \mathrm{H}\right]$ flunitrazepam, $\left[{ }^{3} \mathrm{H}\right] \mathrm{MK}-801$ and $\left[{ }^{3} \mathrm{H}\right]$ nicotine.

The results of the calcium mobilisation assay are presented in Figure 2.
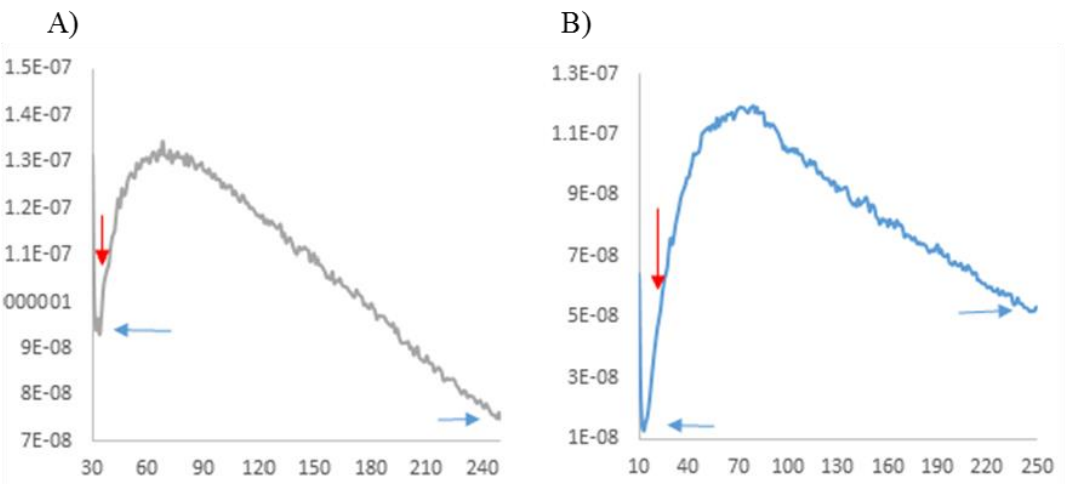

(C)

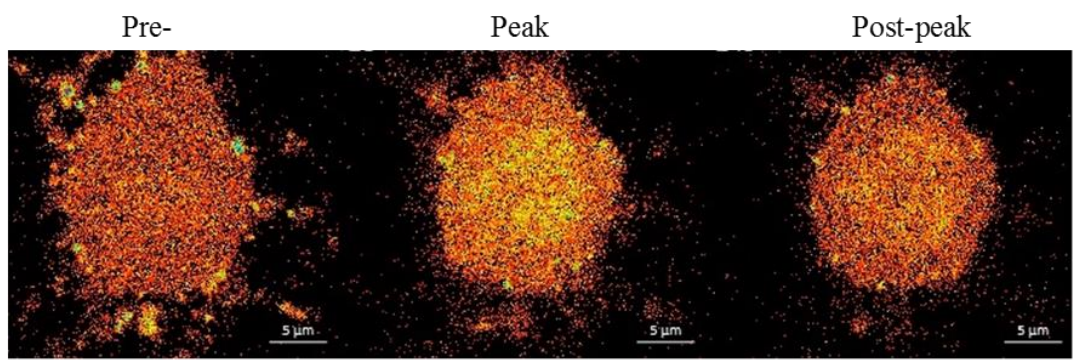

Figure 2. Effects of M. piperita essential oil on Calcium mobilisation in differentiated CAD cells. M. piperita essential oil $(0.1 \mathrm{mg} / \mathrm{mL})$ was applied (red arrow) and recorded for 250 cycles. Representative of at least 5 cells from 3 separate experiments. (A) Positive modulation on calcium intracellular mobilisation. A rapid increase in calcium was observed in the neuronal cell body, which peaked approximated cycle 40 post-application (approx. $30 \mathrm{~s}$ ) and then dropped steadily to a level below the original starting concentration at cycle 250. (B) Extension of depolarization-induced calcium mobilisation. In the presence of $M$. piperita essential oil $(0.1 \mathrm{mg} / \mathrm{mL})$ for approx. $180 \mathrm{~s}$, a depolarisation pulse for 250 cycles elicited a rapid calcium increase followed by a delayed decrease compared to a depolarising pulse alone, which desensitised significantly quicker. (C) Representative images. Representative images of individual cell body calcium changes in the presence of M. piperita essential oil $(0.1 \mathrm{mg} / \mathrm{mL})$, pre-application, peak of calcium increase and post peak reduction in calcium levels. 


\section{Human Intervention Study}

\subsection{Methods}

\subsubsection{Participants}

24 participants (9 Male/15 Female, Mean age 25.2 years, Range 21-35 years) reported themselves to be in good health and free from illicit drugs, alcohol, prescription medication (apart from contraception in the case of women) and herbal extracts/food supplements at each assessment. Participants confirmed that they would also comply with these exclusion criteria for the duration of the study and that any changes in medication or health status would be reported to the researcher when they occurred. Participants who had suffered a head injury, neurological disorder or neuro-developmental disorder were excluded from participation, as were those who did not have English as their 1st language (or were not equivalent to a native English speaker; due to the cognitive tasks utilized here not being validated on non-native English speakers) had any relevant food allergies or intolerances, digestive problems, smoked tobacco, drank excessive amounts of caffeine (more than $600 \mathrm{mg}$ day as assessed by a caffeine consumption questionnaire), were pregnant, seeking to become so, or were breast feeding.

The study received ethical approval from the Northumbria University Psychology department (within the faculty of Health and Life Sciences) ethics committee (code SUB058_Wightman_160216) and was conducted according to the Declaration of Helsinki (1964). All participants gave their written informed consent prior to their inclusion in the study.

\subsubsection{Treatments}

The treatment administered in the study (essential oil number 4) was chosen from six organic essential oils on the basis of the in vitro pre-screening as described above.

On each study day participants received two $500 \mu \mathrm{L}$ capsules containing one of the following treatments:

$100 \mu \mathrm{L}$ Mentha piperita essential oil (in vegetable oil)

$50 \mu \mathrm{L}$ Mentha piperita essential oil (in vegetable oil)

Placebo (vegetable oil)

The individual participants' treatments were administered double-blind in envelopes with a peppermint aroma according to the participant's randomly allocated position on a Latin square counterbalancing the order of treatments across the cohort. Treatment guess data collected at the end of the final study visit showed that participants' ability to identify treatments did not differ from chance. Capsules were consumed with $200 \mathrm{~mL}$ full fat milk (to aid distribution and absorption of lipid soluble terpenes) under constant supervision.

\subsubsection{Cognitive Tasks and Mood Measures}

With the exception of the State-Trait Anxiety Inventory, all cognitive tasks and mood measures were delivered via the Computerised Mental Performance Assessment System (COMPASS; see: www.cognitivetesting.co.uk), a software platform for the presentation of classic and bespoke computerised cognitive tasks, with fully randomised parallel versions of each task delivered at each assessment for each individual. Tasks were presented on a laptop PC with responses made either via a four button response box, with mouse and cursor, or by the keyboard's linear number pad. The tasks and other components of each assessment are described below in order of completion. The timelines of each assessment are shown in Figure 2. Similar selections of tasks have previously been shown to be sensitive to a number of nutritional interventions [11,43,44]. 


\subsubsection{State-Trait Anxiety Inventory (STAI) [45]}

During the training/screening session, participants completed the entire pen and paper STAI to indicate general levels of state and trait anxiety. During the testing session participants completed the state subscale only. The STAI state subscale is a widely used instrument for measuring fluctuating levels of anxiety. The subscale contains 20 statements (e.g., "I am calm") each with a 4-point Likert scale. Participants rate how much they feel like each statement at the time of making the response. Scores on the STAI range from 20 to 80, with higher scores representing higher levels of anxiety.

\subsubsection{Bond-Lader Mood Scales [46]}

These mood scales have been utilised in numerous pharmacological, psychopharmacological and medical trials. These scales comprise a total of sixteen $100 \mathrm{~mm}$ lines anchored at either end by antonyms (e.g., "alert-drowsy," "calm-excited"). Participants indicate their current subjective position between the antonyms on the line. Outcomes comprise three factor analysis derived scores: "Alertness", "Calmness" and "Contentment".

\subsubsection{Picture Presentation}

Fifteen black-and-white photographic images of objects and outdoor and indoor scenes were presented sequentially on screen for the participant to remember at the rate of 1 every $3 \mathrm{~s}$, with a stimulus duration of one second. The same set of fifteen pictures was presented to each participant in a random order.

\subsubsection{Face Presentation}

A set of twelve passport-style photographic images of people were presented sequentially in a random order to participants. A first and last name was assigned to each photograph and presented on the screen underneath the person's face. Stimulus duration was one second, with a 3-second inter-stimulus duration.

\subsubsection{Word Presentation}

A unique set of fifteen words was presented. Words were selected at random from a large bank of words derived from the MRC Psycholinguistic Database [47] and matched for word length, frequency, familiarity and concreteness. Stimulus duration was one second, as was the inter-stimulus duration.

\subsubsection{Immediate Word Recall}

The participant was allowed $60 \mathrm{~s}$ to write down as many of the words as possible. The task was scored for number correct and errors.

\subsubsection{Numeric Working Memory}

Five random digits from 1-9 were presented sequentially for the participant to hold in memory. This was followed by a series of 30 probe digits ( 15 targets and 15 distractors). For each, the participant indicated whether or not it had been in the original series by a simple key press. The task consisted of 3 separate trials. Accuracy (\% correct) and mean reaction time (ms) were recorded.

\subsubsection{Corsi Blocks Task}

In this task, nine identical blue squares appeared on screen in non-overlapping random positions. A set number of blocks changed colour from blue to red in a randomly generated sequence. The cursor was locked in position until the entire sequence had been presented; at which point the participants were instructed to repeat the sequence by clicking on the blocks using the mouse and cursor. The task was repeated five times at each level of difficulty. The sequence span increased from 4 upwards, until 
the participant could no longer correctly recall the sequence, resulting in a span measure of nonverbal working memory, calculated by averaging the level of the last five correctly completed trials.

\subsubsection{Choice Reaction Time (CRT)}

The CRT task requires participants to indicate, by pressing the "left" or "right" response box button, the direction of the arrow presented on the computer screen. Fifty stimuli (arrows) are presented, with varying delays, taking $\sim 2 \mathrm{~min}$ to complete, depending on participant reaction time. The task is scored for percentage correct responses and reaction time (ms).

\subsubsection{RVIP (Completed Separately and as Part of the CDB)}

The RVIP task requires the participant to monitor a continuous series of single digits for targets of three consecutive odd or even numbers. The white digits are presented on the black computer screen at the rate of 100 per minute; with eight correct target strings in each minute presented in pseudo-random order. The participant responds to the detection of a target string by pressing the appropriate response button as quickly as possible. In terms of task outcomes, RVIP is scored for number of target strings correctly detected and the average reaction time (ms) for correct detections.

\subsubsection{Cognitive Demand Battery (CDB)}

Multiple completions of this 9 min battery of tasks reliably increase self-ratings of mental fatigue and is sensitive to many natural interventions [48-51]. Two minutes each of Serial 3 and 7 subtractions is first completed and followed immediately by 5 min of Rapid Visual Information Processing (RVIP—as described above). Mental fatigue is self-rated after each completion of the three tasks.

Serial 3 and 7 subtractions: At the start of the 2 min task a standard instruction screen informs the participant to count backwards in $3 \mathrm{~s}$ or $7 \mathrm{~s}$ as quickly and accurately as possible, using the keyboards linear number keys to enter each response. Participants are instructed verbally at the outset that if they make a mistake they should carry on subtracting from the new incorrect number with subsequent responses scored as correct in relation to the new number. To begin, a random starting number between 800 and 999 is presented on the computer screen, which is cleared by the entry of the first response. Each three-digit response was represented on screen by three asterisks which disappeared after enter was pressed to signal completion of the response. Outcomes are the total number of correct subtractions and the number of incorrect responses.

\subsubsection{Peg and Ball}

Two configurations of wooden peg $(\times 3)$ and ball $(\times 3$; blue, green and red $)$ diagrams are displayed, on screen, with the top diagram denoting the "goal" configuration of balls on pegs. Participants must rearrange the balls on the "starting" configuration below this to match the "goal." They must do this in the least number of moves possible. The task is scored for average thinking time (ms), average completion time (ms) and errors (total number of moves in excess of minimum required to complete all trials).

\subsubsection{Delayed Word Recall}

Participants had $60 \mathrm{~s}$ to note down as many of the words from the list presented at the beginning of the task battery as they can remember. The task was scored for number correct and errors.

\subsubsection{Delayed Face to Name Recall}

The target faces presented at the beginning of the battery were displayed on the screen one at a time. Below each face is a list of 4 forenames and a list of 4 surnames. Participants use the mouse to select the forename and surname that they think were associated with each face at the beginning of the session. The task outcomes include percentage accuracy for overall correct forenames and correct surnames and reaction time (ms). 


\subsubsection{Delayed Picture and Word Recognition}

Word and picture recognition were completed separately. In each task participants differentiate, by pressing "yes" or "no" on the response box, between the 15 target words and pictures presented at the beginning of the test battery and 15 randomly interspersed decoy words and pictures. The tasks take $\sim 2$ min to complete and are scored for percentage of correctly recognised words/pictures and reaction time (ms).

See Figure 3 for the running order of the individual cognitive assessments within the 75 min task battery.

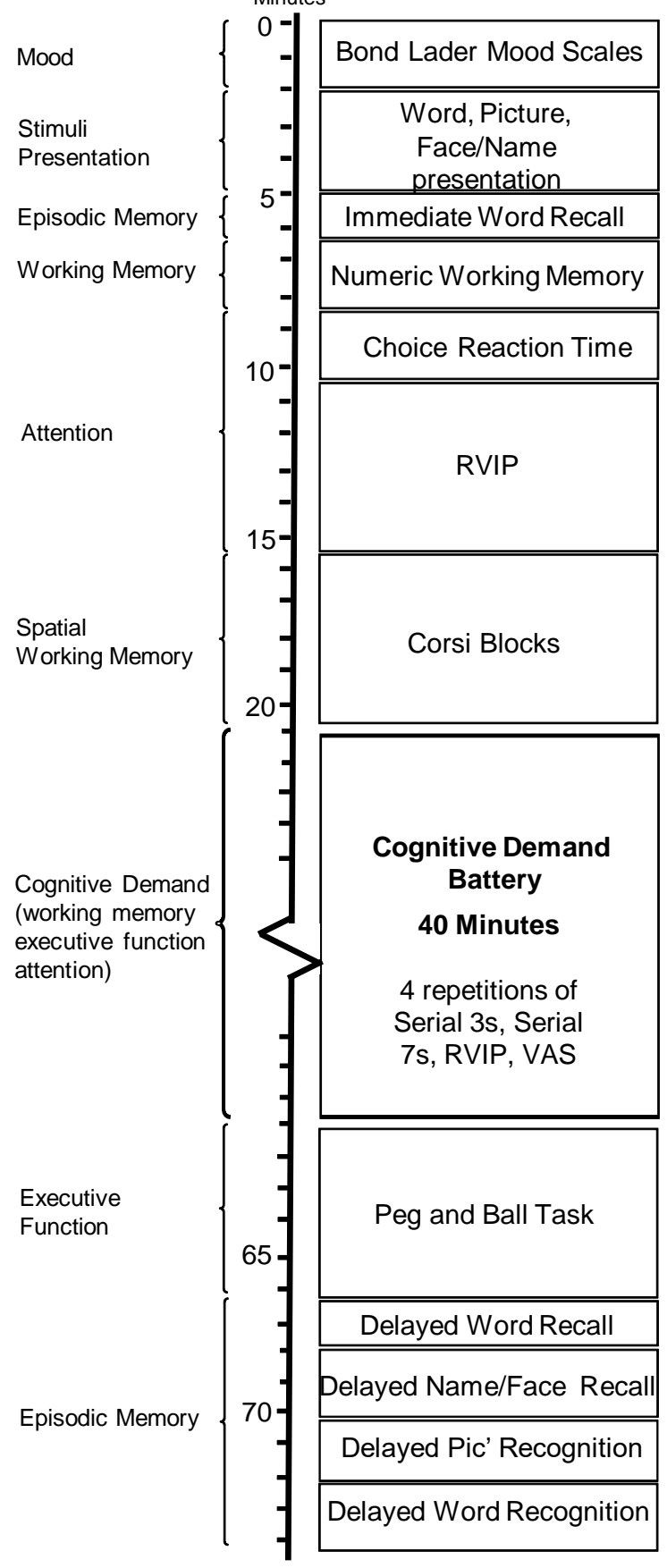

Figure 3. Running order of tasks administered during each assessment. 


\subsection{Procedure}

Participants were required to attend the laboratory on 4 separate occasions, the last three of which were separated by a 7 day wash-out period. The first of the visits was a training/screening session where participants gave consent and were briefed and screened against the exclusion criteria before completing several repetitions of the cognitive tasks described above to ensure they were familiar and capable of completing the tasks during the ensuing testing sessions.

The further 3 visits were testing sessions in which participants arrived at the testing facility at 8:00 a.m., having consumed no food for $12 \mathrm{~h}$, caffeine for $18 \mathrm{~h}$, alcohol for $24 \mathrm{~h}$ and mint-containing products for $48 \mathrm{~h}$. Upon arrival, participants were screened to ensure that they still met the inclusion criteria and their light breakfast (to have been consumed before 7:30 a.m.) was noted. They then underwent a baseline cognitive and mood measurement at 8:15 a.m. Here the "state" subscale of the STAI was completed first followed by the $75 \mathrm{~min}$ cognitive testing battery (see Figure 3). Treatment capsules were then immediately consumed in the presence of the researcher. The cognitive assessment was then repeated commencing at $1 \mathrm{~h}, 3 \mathrm{~h}$ and $6 \mathrm{~h}$ post-dose, with a standard lunch provided after the $3 \mathrm{~h}$ post-dose assessment. During breaks between testing participants waited in a comfortable waiting room. The timelines of the testing day are represented in Figure 4 .

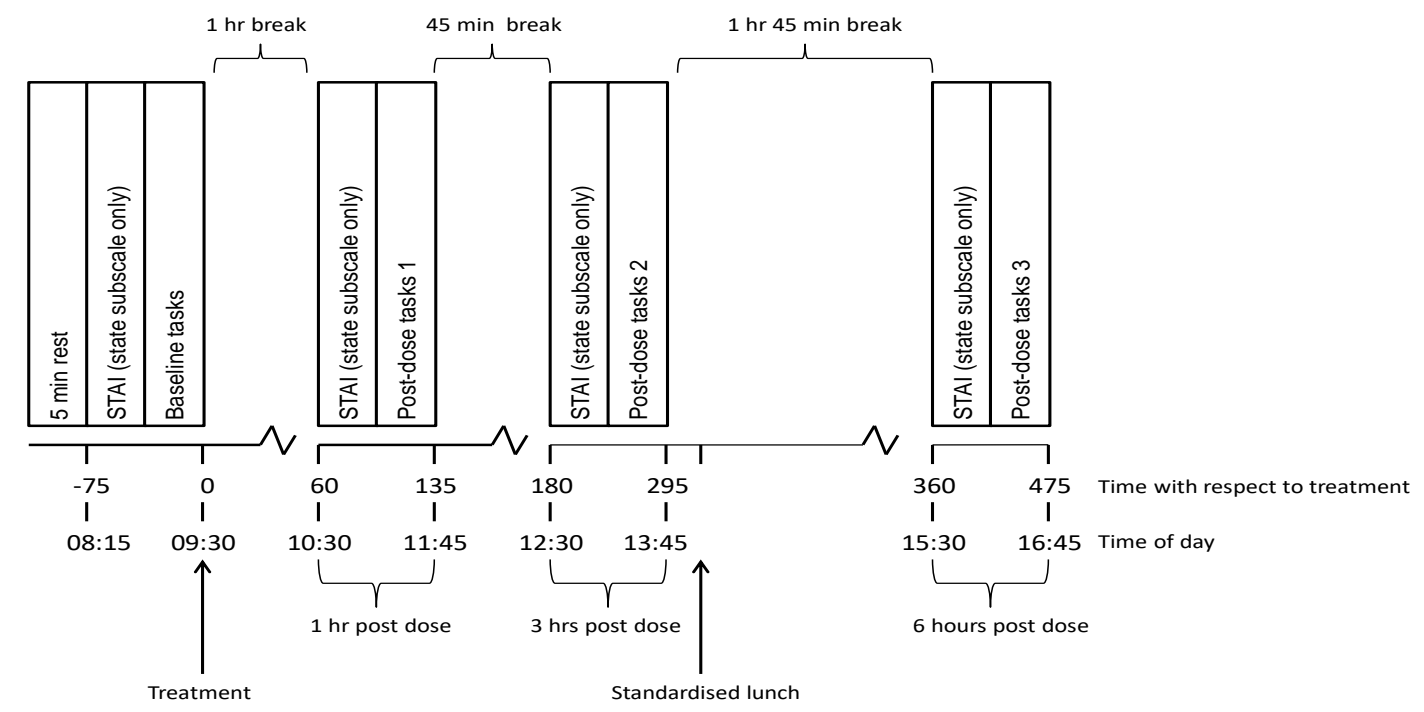

Figure 4. Testing session timeline for all visits.

\subsection{Statistics}

Statistical analyses were carried out using IBM SPSS statistics 22. Prior to analysis, task/mood data from the three post-dose assessments $(1 \mathrm{~h}, 3 \mathrm{~h}, 6 \mathrm{~h})$ was converted to $\%$ change from pre-dose baseline" (Serial $3 \mathrm{~s} / 7 \mathrm{~s}$ errors and Word Recall scores were analysed as simple numeric "change from baseline" due to the potential to score zero at baseline). In order to examine the time course of any effects of the essential oils across the testing day, the primary analysis of all task/mood data was undertaken with a priori planned comparisons, comparing data (averaged across 4 repetitions for CDB tasks) from the placebo condition to that from each of the two active treatments at each post-dose time point using $t$ tests calculated using MSError from an initial omnibus within-subjects ANOVA. To reduce the possibility of Type II errors, planned comparisons are only reported for those measures that evinced a significant treatment related effect on the initial ANOVA or related multivariate test.

\subsection{Results}

Prior to the treatment code break and the analysis of cognitive task performance two participants were removed from the dataset due to inconsistent performance. 


\subsubsection{Cognitive Demand Battery}

\section{Mental Fatigue}

Reference to the planned comparisons of \% change from baseline data showed that subjective ratings of Mental Fatigue were significantly reduced in comparison to placebo following the higher dose of $100 \mu \mathrm{L}$ of essential oil during the $3 \mathrm{~h}$ post-dose assessment $(\mathrm{T}(264)=2.92, p<0.01)$. (Multivariate treatment $x$ assessment interaction $(F(4,19)=3.56, p<0.05)$ ).

\section{Rapid Visual Information Processing Task}

Reference to the planned comparisons of \% change from baseline data showed that, in comparison to placebo, accuracy on the RVIP task was significantly enhanced following the higher dose $(100 \mu \mathrm{L})$ of essential oil during the $1 \mathrm{~h}(\mathrm{~T}(252)=2.88, p<0.01)$ and $3 \mathrm{~h}(\mathrm{~T}(252)=2.04, p<0.05)$ post-dose assessments. (Multivariate main effect of treatment $(\mathrm{F}(2,20)=3.84, p<0.05)$ ).

\section{Serial 3 s Subtractions}

Reference to the planned comparisons of $\%$ change from baseline data showed that, in comparison to placebo, participants completed more correct Serial $3 \mathrm{~s}$ following the higher dose $(100 \mu \mathrm{L})$ of essential oil during the $3 \mathrm{~h}(\mathrm{~T}(252)=2.92, p<0.01)$ post-dose assessment. (ANOVA treatment $\mathrm{x}$ assessment interaction $(\mathrm{F}(4,252)=2.64, p<0.05))$.

Serial $7 \mathrm{~s}$ Subtractions

Whilst there was a treatment $x$ assessment interaction effect with regards Serial $7 \mathrm{~s}$ errors (ANOVA $(\mathrm{F}(4,252)=3.3, p<0.05)$ this only resulted in a trend towards reduced errors following the higher dose, relative to placebo, during the $3 \mathrm{~h}$ assessment $(\mathrm{T}(252)=1.9, p<0.1)$.

The measures evincing significant treatment related improvements are represented graphically in Figure 5. Data for the Cognitive Demand Battery tasks are presented in Table 2.

Table 2. Cognitive Demand Battery pre-dose baseline (raw) data and "\% change from baseline" data for the $1 \mathrm{~h}, 3 \mathrm{~h}$ and $6 \mathrm{~h}$ assessments. Serial $3 \mathrm{~s} / 7 \mathrm{~s}$ errors post-dose scores are "change from baseline" (due to potential zero scores). All data shown are average scores across the 4 repetitions of each task during each assessment. Scores are mean (+ SEM).

\begin{tabular}{|c|c|c|c|c|c|c|c|c|c|}
\hline \multirow{5}{*}{$\begin{array}{l}\text { TASK } \\
\begin{array}{l}\text { ntal Fatigue } \\
(\% \text { VAS })\end{array}\end{array}$} & \multirow{3}{*}{$\begin{array}{c}\text { Treatment } \\
100 \mu \mathrm{L}\end{array}$} & \multicolumn{8}{|c|}{ Assessment } \\
\hline & & \multicolumn{2}{|c|}{ Baseline } & \multicolumn{2}{|c|}{$1 \mathrm{~h}$} & \multicolumn{2}{|c|}{$3 \mathrm{~h}$} & \multicolumn{2}{|c|}{$6 \mathrm{~h}$} \\
\hline & & 61.81 & 4.08 & 11.46 & 5.32 & 10.16 & 6.40 & 21.42 & 7.92 \\
\hline & $50 \mu \mathrm{L}$ & 58.10 & 3.92 & 12.43 & 7.26 & 17.70 & 7.55 & 26.28 & 7.73 \\
\hline & placebo & 57.53 & 3.86 & 9.13 & 5.54 & 23.16 & 6.21 & 24.63 & 5.78 \\
\hline & $100 \mu \mathrm{L}$ & 51.05 & 4.55 & 2.78 & 4.01 & -8.29 & 2.51 & -9.77 & 2.91 \\
\hline \multirow[t]{3}{*}{ RVIP (\% correct) } & $50 \mu \mathrm{L}$ & 57.19 & 4.01 & -4.47 & 3.27 & -13.07 & 3.37 & -13.4 & 3.66 \\
\hline & placebo & 54.43 & 3.72 & -11.96 & 4.30 & -15.73 & 3.23 & -18.2 & 3.32 \\
\hline & $100 \mu \mathrm{L}$ & 477.11 & 9.68 & -2.21 & 0.97 & -2.97 & 1.13 & -2.40 & 1.43 \\
\hline \multirow[t]{2}{*}{ RVIP (speed-ms) } & $50 \mu \mathrm{L}$ & 474.48 & 11.47 & -0.13 & 0.66 & -0.45 & 0.59 & -1.04 & 0.99 \\
\hline & placebo & 484.23 & 11.67 & -2.88 & 0.80 & -1.95 & 0.95 & -2.53 & 1.07 \\
\hline \multirow{3}{*}{$\begin{array}{c}\text { Serial 7 s } \\
\text { (number correct) }\end{array}$} & $100 \mu \mathrm{L}$ & 29.17 & 2.24 & 6.22 & 2.18 & 9.90 & 4.29 & 8.34 & 3.52 \\
\hline & $50 \mu \mathrm{L}$ & 29.11 & 2.55 & 4.75 & 3.00 & 10.11 & 3.15 & 8.21 & 4.18 \\
\hline & placebo & 28.86 & 2.58 & 8.89 & 4.87 & 9.11 & 3.64 & 10.08 & 4.65 \\
\hline \multirow{3}{*}{$\begin{array}{l}\text { Serial 7 s } \\
\text { (errors) }\end{array}$} & $100 \mu \mathrm{L}$ & 2.24 & 0.33 & 0.05 & 0.26 & 0.51 & 0.32 & -0.15 & 0.25 \\
\hline & $50 \mu \mathrm{L}$ & 1.91 & 0.32 & 0.00 & 0.32 & 0.39 & 0.19 & -0.10 & 0.38 \\
\hline & placebo & 2.08 & 0.36 & -0.28 & 0.27 & 0.20 & 0.33 & -0.40 & 0.27 \\
\hline \multirow{3}{*}{$\begin{array}{c}\text { Serial 3s } \\
\text { (number correct) }\end{array}$} & $100 \mu \mathrm{L}$ & 46.83 & 3.48 & 5.14 & 2.28 & 11.59 & 3.83 & 7.50 & 3.09 \\
\hline & $50 \mu \mathrm{L}$ & 46.93 & 3.77 & 4.17 & 2.44 & 5.64 & 4.14 & 2.59 & 3.55 \\
\hline & placebo & 46.61 & 3.50 & 3.96 & 2.26 & 1.83 & 2.27 & 5.14 & 2.61 \\
\hline \multirow{3}{*}{$\begin{array}{l}\text { Serial 3 s } \\
\text { (errors) }\end{array}$} & $100 \mu \mathrm{L}$ & 2.19 & 0.36 & 0.47 & 0.33 & -0.33 & 0.41 & 0.13 & 0.22 \\
\hline & $50 \mu \mathrm{L}$ & 2.44 & 0.43 & -0.56 & 0.28 & 0.01 & 0.49 & 0.60 & 0.29 \\
\hline & placebo & 1.60 & 0.26 & -0.27 & 0.30 & -0.48 & 0.37 & -0.34 & 0.19 \\
\hline
\end{tabular}



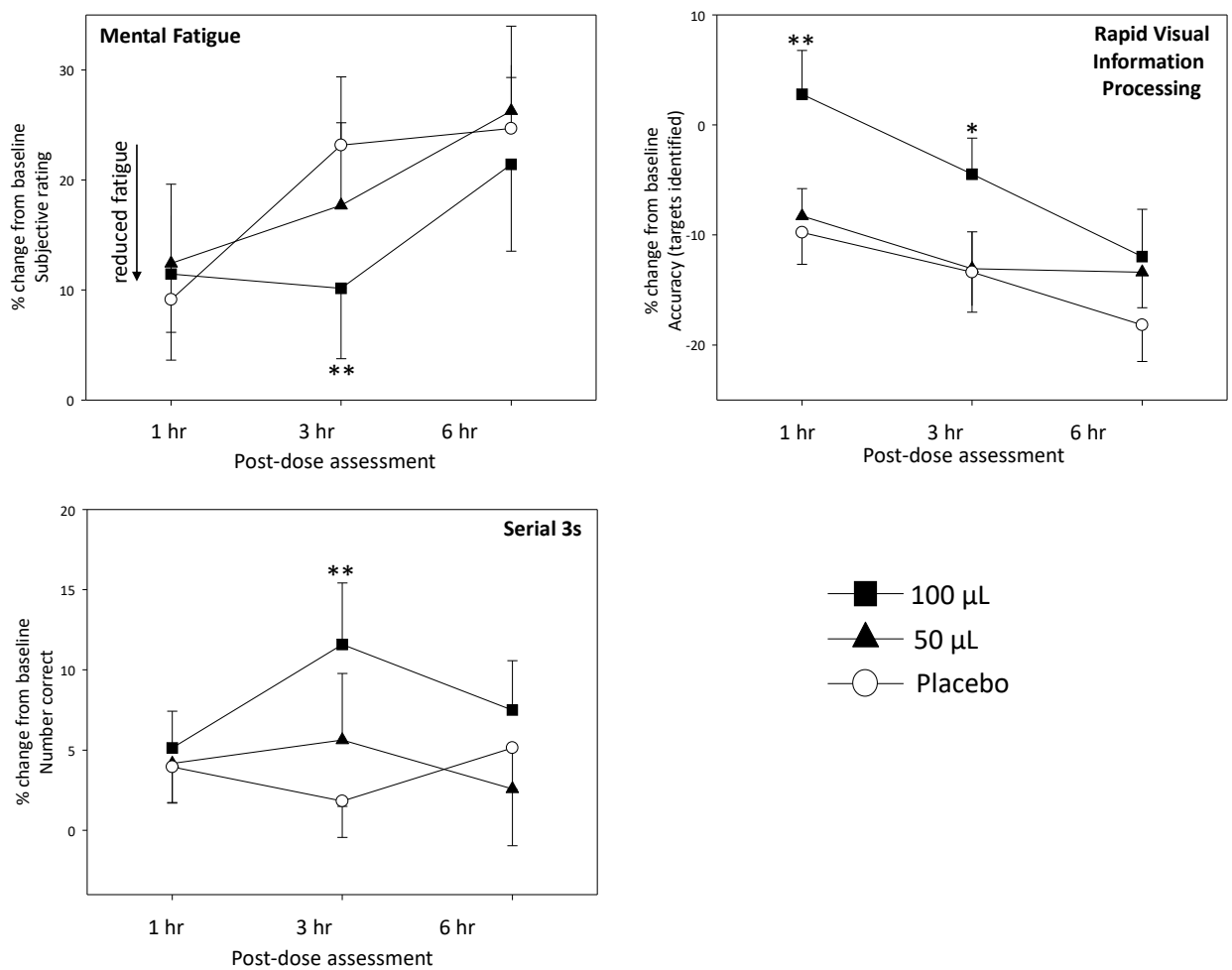

Figure 5. Effects of peppermint (Mentha $\times$ piperita) essential oil on the performance of the Cognitive Demand Battery tasks during the $1 \mathrm{~h}, 3 \mathrm{~h}$ and $6 \mathrm{~h}$ assessments. Data are mean $( \pm \mathrm{SEM}) \%$ change from pre-dose baseline. Asterisks represent a significant difference to placebo from the a priori planned comparisons. ${ }^{*}, p<0.05 ; * *, p<0.01$.

\subsubsection{Individual Cognitive Tasks}

Word Recall errors was the only individual cognitive task outcome to evince a significant ANOVA result $(\mathrm{F}(4,88)=5.4, p<0.001)$. However, reference to the planned comparisons showed that there were no significant differences between placebo and the low and high doses of essential oil. The data from the individual cognitive tasks are presented in the on-line Supplementary Table S2.

\subsubsection{Mood}

There were no significant differences on the mood measures (State-Trait Anxiety Inventory-state subscale and Bond-Lader "alert," "content" and "calm").

The data from the mood measures are presented in the on-line Supplementary Table S3.

\section{Discussion}

In this study, the peppermint (Mentha $\times$ piperita) essential oil selected for the human behavioural study exhibited in vitro concentration-dependent $\mathrm{GABA}_{\mathrm{A}}$ and nicotinic receptor binding properties and inhibited acetylcholinesterase. When administered to human adults the higher dose of essential oil $(100 \mu \mathrm{L})$ resulted in improvements in performance across two of the three Cognitive Demand Battery (CDB) tasks, with a trend towards improved performance on the third task. In terms of individual tasks, the accuracy of performing the RVIP task was significantly improved during the $1 \mathrm{~h}$ and $3 \mathrm{~h}$ post-dose assessments, whilst the number of correct Serial 3s subtractions was significantly increased at $3 \mathrm{~h}$ post-dose. This latter finding also coincided with a trend towards improved accuracy on the Serial 7s task and a significant attenuation of the subjective mental fatigue experienced by the placebo group at the same time point. Performance on the individual cognitive tasks (i.e., those only repeated 
once per assessment) and measurements of anxiety (STAI-state) and psychological state (Bond-Lader) were not modulated by the treatment.

Naturally, this pattern of effects raises the question as to why performance of the CDB was preferentially affected. The underlying rationale for this approach to testing, whereby participants engage in an extended period of demanding task performance, is that the increase in neuronal or psychological demands provides a more sensitive background against which to measure treatment related effects. This may be due either to the rate-limiting depletion of physiological brain resources during extended task performance, or alternatively, the increased level of engagement required by the participants. Certainly, this approach has proved sensitive to the cognitive/mental fatigue effects of a wide range of nutritional interventions [11,50,52]. An alternative explanation might be that the CDB involves four repetitions of each task (i.e., 4 times as much data), thereby increasing the statistical power of these measures to detect treatment related effects.

In terms of in vitro properties, all of the spearmint/peppermint oils were confirmed to have the expected terpene constituents (as defined in the British Pharmacopoeia (www.pharmacopoeia.co.uk), with the spearmints typified by high levels of limonene and carvone, while the peppermints contained high levels of menthol and menthone (see Table 1). The essential oil chosen for the behavioural study had the highest level of menthol (36.7\%) and it exhibited both concentration dependent GABA $\mathrm{A}$ and nicotinic receptor binding properties, alongside significant inhibition of acetylcholinesterase (thereby potentially increasing the synaptic availability of acetylcholine). The GABAergic and cholinesterase inhibitory effects are broadly in line with previous investigations of Mentha $\times$ piperita [42] and other members of the Mentha genus [53]. With regards the nicotinic receptor binding, whilst there is a dearth of research assessing the effects of $M$. piperita extracts per se, menthol has been shown to modulate nicotinic receptor populations and sensitivity and inhibit nicotinic receptor mediated activity $[41,54]$. Similar observations have been noted with the essential oil from another member of the Lamiaceae, Melissa officinalis (Chazot, unpublished). In the current study, the post-hoc investigation of calcium mobilisation in a CAD cell neuronal model showed an increase in activity following application of the essential oil. It seems likely that the effects here were predicated on cholinergic upregulation, rather than any aspect of GABAergic modulation. Indeed, the behavioural consequences of increased GABAergic activity (which is inhibitory) would be expected to include modulation of mood and anxiolytic properties and potential selective impairments to cognitive function. Here, the improved performance on the Cognitive Demand Battery; which requires considerable attentional resources, would fit well with the theory of upregulated cholinergic activity. The disjunction between observations of in vitro downregulation of nicotinic receptor mediated activity by menthol [41,54] and potential cholinergic improvements in cognitive function and mental fatigue following the essential oil could be explained by several factors. First, the effects here could have been predicated on synergistic effects between component terpenes; with menthol contributing to, rather than driving the effects of the essential oil. Such synergistic effects have been seen previously with regards, for instance, AChE inhibition [12,13]. Second and similarly, the effects may have represented the balance between menthol's receptor mediated downregulation of nicotinic activity and the essential oil's AChE inhibition related upregulation of acetylcholine levels. Third, in vitro effects are typically measured within a short period of application and the behavioural effects here may be predicated on later effects that are different in nature, including a potential physiological "rebound" triggered by the immediate effects on cellular function. Fourth, the cholinergic effects of menthol may differ depending on the nature of the neural tissue (e.g., downregulation has typically been shown in sensory neurons). Peppermint (Mentha $\times$ piperita) essential oil also elicited an increase in $\left[\mathrm{Ca}^{2+}\right]$ and an extension of the depolarisation response as previously reported for menthol; a major constituent of the oil [55]. The neuroprotective properties in the face of oxidative stress displayed by M. piperita in CAD cells (online Supplementary Appecndix I) is consistent with a previous study with a related cell line [42]. These pharmacological functional effects may also contribute, in part, to the positive cognitive effects 
of M. piperita. Of course, the net effects of the essential oil may be a result of a combination of these factors or, indeed, a host of other mechanisms of action that were not addressed in this study.

Interestingly, a previous study that assessed the cognitive effects of $50 \mu \mathrm{L}$ of essential oil from sage (Salvia lavandulaefolia Vahl.; synonym for Salvia officinalis subsp. lavandulifolia (Vahl) Gams), which is in the same sub-family as M. piperita and synthesises many similar monoterpenes, demonstrated decreased mental fatigue and improved Serial 3 s subtractions using the same Cognitive Demand Battery [11]. As here, the effects were greater at a later time point ( $4 \mathrm{~h}$ post-dose) than at $1 \mathrm{~h}$ post-dose. In the previous sage study the cognitive effects also extended to the other individual cognitive tasks and included improved alertness and memory. The lower dose for the current study was selected on the basis of this previous study and given that the lower dose $(50 \mu \mathrm{L})$ administered here was less effective, it seems likely that $100 \mu \mathrm{L}$ of $M$. piperita essential oil may represent the lower reaches of this oil's dose-response profile. If this is the case, higher doses of this oil may well result in a more comprehensive pattern of cognitive/mood effects. This possibility, alongside research disentangling the behavioural effects of the major components of these essential oils, deserves further research attention.

In conclusion, a peppermint (M. piperita) essential oil with high levels of menthol and menthone and characteristic in vitro $\mathrm{AChE}$ inhibitory, calcium regulatory, $\mathrm{GABA}_{\mathrm{A}}$ receptor and nicotinic receptor binding properties, beneficially modulated performance of demanding cognitive tasks and attenuated the increase in mental fatigue associated with extended cognitive testing. These effects were only evident for the higher $(100 \mu \mathrm{L})$ of the two doses investigated; raising the possibility that doses of this essential oil in excess of $100 \mu \mathrm{L}$ would exert greater effects in terms of cognitive/mood enhancement.

Supplementary Materials: The following are available online at http:/ /www.mdpi.com/2072-6643/10/8/1029/s1, Table S1: Percentage composition of compounds detected in the Mentha spicata and Mentha $\times$ piperita essential oils, obtained from the GC-MS total ion chromatograms, Table S2: Individual cognitive task performance: pre-dose baseline (raw) data and '\% change from baseline' data for the $1 \mathrm{~h}, 3 \mathrm{~h}$ and $6 \mathrm{~h}$ assessments. Immediate and Delayed Word Recall correct and error post-dose scores are 'change from baseline' (due to potential zero scores). Scores are mean (+ SEM), Table S3: Mood data: pre-dose baseline (raw) data and '\% change from baseline' data for the $1 \mathrm{~h}$, $3 \mathrm{~h}$ and $6 \mathrm{~h}$ assessments. Appendix I: in vitro neuroprotective properties-method and results.

Author Contributions: E.W., D.K., P.J. and C.H.-R. were actively involved in the planning of the research described herein. E.O., S.O. and P.C. devised the methods for and conducted the in vitro analyses. M.-J.H. performed the chemical analysis studies. J.K. and J.F. collected the data and all authors contributed to and reviewed the final publication.

Funding: This study was funded by Procter and Gamble $\left(P \& G^{\mathrm{TM}}\right)$ who collaborated on aspects of the design but had no further involvement in the study. PC would also like to thank Alzheimer's Research UK for financial support.

Conflicts of Interest: The authors declare no conflict of interest.

\section{References}

1. İşcan, G.; Kirimer, N.; Kürkcüoğlu, M.; Başer, H.C.; DEMIrci, F. Antimicrobial screening of mentha piperita essential ils. J. Agric. Food Chem. 2002, 50, 3943-3946. [CrossRef] [PubMed]

2. Abuhamdah, S.; Huang, L.; Elliott, M.S.; Howes, M.J.R.; Ballard, C.; Holmes, C.; Burns, A.; Perry, E.K.; Francis, P.T.; Lees, G. Pharmacological profile of an essential oil derived from melissa officinalis with anti-agitation properties: Focus on ligand-gated channels. J. Pharm. Pharmacol. 2008, 60, 377-384. [CrossRef] [PubMed]

3. Kennedy, D.; Little, W.; Haskell, C.F.; Scholey, A.B. Anxiolytic effects of a combination of melissa officinalis and valeriana officinalis during laboratory induced stress. Phytother. Res. 2006, 20, 96-102. [CrossRef] [PubMed]

4. Kennedy, D.O.; Little, W.; Scholey, A.B. Attenuation of laboratory-induced stress in humans after acute administration of melissa officinalis (Lemon balm). Psychosom. Med. 2004, 66, 607-613. [CrossRef] [PubMed]

5. Kennedy, D.O.; Scholey, A.B.; Tildesley, N.T.J.; Perry, E.K.; Wesnes, K.A. Modulation of mood and cognitive performance following acute administration of melissa officinalis (Lemon balm). Pharmacol. Biochem. Behav. 2002, 72, 953-964. [CrossRef] 
6. Perry, N.; Menzies, R.; Hodgson, F.; Wedgewood, P.; Howes, M.-J.; Brooker, H.; Wesnes, K.; Perry, E. A randomised double-blind placebo-controlled pilot trial of a combined extract of sage, rosemary and melissa, traditional herbal medicines, on the enhancement of memory in normal healthy subjects, including influence of age. Phytomedicine 2018, in press. [CrossRef] [PubMed]

7. Tildesley, N.T.J.; Kennedy, D.O.; Perry, E.K.; Ballard, C.G.; Wesnes, K.A.; Scholey, A.B. Positive modulation of mood and cognitive performance following administration of acute doses of Salvia lavandulaefolia essential oil to healthy young volunteers. Physiol. Behav. 2005, 83, 699-709. [CrossRef] [PubMed]

8. Scholey, A.B.; Tildesley, N.T.J.; Ballard, C.G.; Wesnes, K.A.; Tasker, A.; Perry, E.K.; Kennedy, D.O. An extract of salvia (sage) with anticholinesterase properties improves memory and attention in healthy older volunteers. Psychopharmacology 2008, 198, 127-139. [CrossRef] [PubMed]

9. Perry, N.; Court, G.; Bidet, N.; Court, J.; Perry, E. European herbs with cholinergic activities: Potential in dementia therapy. Int. J. Geriatr. Psychiatry 1996, 11, 1063-1069. [CrossRef]

10. Perry, N.; Houghton, P.; Theobald, A.; Jenner, P.; Perry, E. In-vitro inhibition of human erythrocyte acetylcholinesterase by Salvia lavandulaefolia essential oil and constituent terpenes. J. Pharm. Pharmacol. 2000, 52, 895-902. [CrossRef] [PubMed]

11. Kennedy, D.O.; Dodd, F.L.; Robertson, B.C.; Okello, E.J.; Reay, J.L.; Scholey, A.B.; Haskell, C.F. Monoterpenoid extract of sage (Salvia lavandulaefolia) with cholinesterase inhibiting properties improves cognitive performance and mood in healthy adults. J. Psychopharmacol. 2011, 25, 1088-1100. [CrossRef] [PubMed]

12. Savelev, S.; Okello, E.; Perry, N.S.L.; Wilkins, R.M.; Perry, E.K. Synergistic and antagonistic interactions of anticholinesterase terpenoids in Salvia lavandulaefolia essential oil. Pharmacol. Biochem. Behav. 2003, 75, 661-668. [CrossRef]

13. Savelev, S.U.; Okello, E.J.; Perry, E.K. Butyryl- and acetyl-cholinesterase inhibitory activities in essential oils of salvia species and their constituents. Phytother. Res. 2004, 18, 315-324. [CrossRef] [PubMed]

14. Moss, L.; Rouse, M.; Wesnes, K.; Moss, M. Differential effects of the aromas of salvia species on memory and mood. Hum. Psychopharmacol. Clin. Exp. 2010, 25, 388-396. [CrossRef] [PubMed]

15. Diego, M.A.; Jones, N.A.; Field, T.; Hernandez-Reif, M.; Schanberg, S.; Kuhn, C.; Galamaga, M.; McAdam, V.; Galamaga, R. Aromatherapy positively affects mood, EEG patterns of alertness and math computations. Int. J. Neurosci. 1998, 96, 217-224. [CrossRef] [PubMed]

16. Moss, M.; Cook, J.; Wesnes, K.; Duckett, P. Aromas of rosemary and lavender essential oils differentially affect cognition and mood in healthy adults. Int. J. Neurosci. 2003, 113, 15-38. [CrossRef] [PubMed]

17. Asao, T.; Mochiki, E.; Suzuki, H.; Nakamura, J.-I.; Hirayama, I.; Morinaga, N.; Shoji, H.; Shitara, Y.; Kuwano, H. An easy method for the intraluminal administration of peppermint oil before colonoscopy and its effectiveness in reducing colonic spasm. Gastrointest. Endos. 2001, 53, 172-177. [CrossRef]

18. Tate, S. Peppermint oil: A treatment for postoperative nausea. J. Adv. Nurs. 1997, 26, 543-549. [CrossRef] [PubMed]

19. McKay, D.L.; Blumberg, J.B. A review of the bioactivity and potential health benefits of peppermint tea (Mentha piperita L.). Phytother. Res. 2006, 20, 619-633. [CrossRef] [PubMed]

20. Ferreira, A.; Proença, C.; Serralheiro, M.; Araújo, M. The in vitro screening for acetylcholinesterase inhibition and antioxidant activity of medicinal plants from portugal. J. Ethnopharmacol. 2006, 108, 31-37. [CrossRef] [PubMed]

21. Heimes, K.; Hauk, F.; Verspohl, E.J. Mode of action of peppermint oil and (-)-menthol with respect to 5-HT 3 receptor subtypes: Binding studies, cation uptake by receptor channels and contraction of isolated rat ileum. Phytother. Res. 2011, 25, 702-708. [CrossRef] [PubMed]

22. Sánchez-Borzone, M.; Delgado-Marin, L.; García, D.A. Inhibitory effects of carvone isomers on the GABAA receptor in primary cultures of rat cortical neurons. Chirality 2014, 26, 368-372. [CrossRef] [PubMed]

23. Hall, A.C.; Turcotte, C.M.; Betts, B.A.; Yeung, W.-Y.; Agyeman, A.S.; Burk, L.A. Modulation of human GABAA and glycine receptor currents by menthol and related monoterpenoids. Eur. J. Pharmacol. 2004, 506, 9-16. [CrossRef] [PubMed]

24. Zhang, X.-B.; Jiang, P.; Gong, N.; Hu, X.-L.; Fei, D.; Xiong, Z.-Q.; Xu, L.; Xu, T.-L. A-type GABA receptor as a central target of TRPM8 agonist menthol. PLoS ONE 2008, 3, e3386. [CrossRef] [PubMed]

25. Lau, B.K.; Karim, S.; Goodchild, A.K.; Vaughan, C.W.; Drew, G.M. Menthol enhances phasic and tonic gabaa receptor-mediated currents in midbrain periaqueductal grey neurons. Br. J. Pharmacol. 2014, 171, 2803-2813. [CrossRef] [PubMed] 
26. Journigan, V.B.; Zaveri, N.T. TRPM8 ion channel ligands for new therapeutic applications and as probes to study menthol pharmacology. Life Sci. 2013, 92, 425-437. [CrossRef] [PubMed]

27. Galeotti, N.; Mannelli, L.D.C.; Mazzanti, G.; Bartolini, A.; Ghelardini, C. Menthol: A natural analgesic compound. Neurosci. Lett. 2002, 322, 145-148. [CrossRef]

28. Umezu, T.; Sakata, A.; Ito, H. Ambulation-promoting effect of peppermint oil and identification of its active constituents. Pharmacol. Biochem. Behav. 2001, 69, 383-390. [CrossRef]

29. Umezu, T. Evaluation of the effects of plant-derived essential oils on central nervous system function using discrete shuttle-type conditioned avoidance response in mice. Phytother. Res. 2012, 26, 884-891. [CrossRef] [PubMed]

30. Parveen, T.; Amin, N.; Saleem, D.; Razi, F.; Haider, S.; Haleem, D.J. Antistress effect of mentha piperita in rats and the role of brain serotonin and dopamine. Asian J. Pharm. Biol. Res. 2012, 2, 73-78.

31. Umezu, T. Evaluation of central nervous system acting effects of plant-derived essential oils using ambulatory activity in mice. Pharmacol. Pharm. 2013, 4, 160. [CrossRef]

32. Jasira, M.; Sai-Sailesh, K. Oral administration of peppermint in wistar albino rats: Memory boosting and regaining. Indones. J. Biomed. Sci. 2013, 7, 23-26.

33. Wake, G.; Court, J.; Pickering, A.; Lewis, R.; Wilkins, R.; Perry, E. Cns acetylcholine receptor activity in european medicinal plants traditionally used to improve failing memory. J. Ethnopharmacol. 2000, 69, 105-114. [CrossRef]

34. Herrlinger, K.A.; Nieman, K.M.; Sanoshy, K.D.; Fonseca, B.A.; Lasrado, J.A.; Schild, A.L.; Maki, K.C.; Wesnes, K.A.; Ceddia, M.A. Spearmint extract improves working memory in men and women with age-associated memory impairment. J. Altern. Complement. Med. 2018, 24, 37-47. [CrossRef] [PubMed]

35. Abuhamdah, S.; Abuhamdah, R.; Howes, M.J.R.; Al-Olimat, S.; Ennaceur, A.; Chazot, P.L. Pharmacological and neuroprotective profile of an essential oil derived from leaves of aloysia citrodora palau. J. Pharm. Pharmacol. 2015, 67, 1306-1315. [CrossRef] [PubMed]

36. Ellman, G. A new and rapid colorimetric determination of acetylcholinesterase activity. Biochem. Pharmacol. 1961, 7, 88. [CrossRef]

37. Okello, E.J.; Dimaki, C.; Howes, M.J.; Houghton, P.J.; Perry, E.K. In vitro inhibition of human acetyl- and butyryl-cholinesterase by Narcissus poeticus L. (amaryllidaceae) flower absolute. Int. J. Essent. Oil Ther. 2008, 2, 105-110.

38. Adams, R.P. Identification of Essential Oil Components by Gas Chromatography/Mass Spectroscopy; Allured Publishing Corporation: Carol Stream, IL, USA, 2007.

39. National Institute of Standards and Technology (NIST). NIST/EPA/NIH Mass Spectral Database; NIST: Gaithersburg, MD, USA, 2008.

40. Farco, J.; Grundmann, O. Menthol-pharmacology of an important naturally medicinal "cool”. Mini Rev. Med. Chem. 2013, 13, 124-131. [CrossRef] [PubMed]

41. Hans, M.; Wilhelm, M.; Swandulla, D. Menthol suppresses nicotinic acetylcholine receptor functioning in sensory neurons via allosteric modulation. Chem. Senses 2012, 37, 463-469. [CrossRef] [PubMed]

42. Lopez, V.; Martin, S.; Gomez-Serranillos, M.P.; Carretero, M.E.; Jager, A.K.; Calvo, M.I. Neuroprotective and neurochemical properties of mint extracts. Phytother. Res. 2010, 24, 869-874. [PubMed]

43. Stonehouse, W.; Conlon, C.A.; Podd, J.; Hill, S.R.; Minihane, A.M.; Haskell, C.; Kennedy, D. DHA supplementation improved both memory and reaction time in healthy young adults: A randomized controlled trial. Am. J. Clin. Nutr. 2013, 97, 1134-1143. [CrossRef] [PubMed]

44. Veasey, R.C.; Gonzalez, J.T.; Kennedy, D.O.; Haskell, C.F.; Stevenson, E.J. Breakfast consumption and exercise interact to affect cognitive performance and mood later in the day. A randomized controlled trial. Appetite 2013, 68, 38-44. [CrossRef] [PubMed]

45. Speilberger, C.D.; Gorsuch, R.L.; Lushene, R.E. The State Trait Anxiety Inventory Manual; Consulting Psychologists Press: Palo Alto, CA, USA, 1969.

46. Bond, A.; Lader, M. Use of analog scales in rating subjective feelings. Br. J. Med. Psychol. 1974, 47, $211-218$. [CrossRef]

47. The Psychological Image Collection at Stirling (PICS). Available online: http://pics.Psych.Stir.Ac.Uk/ (accessed on 20 February 2007). 
48. Kennedy, D.; Haskell, C.; Robertson, B.; Reay, J.; Brewster-Maund, C.; Luedemann, J.; Maggini, S.; Ruf, M.; Zangara, A.; Scholey, A. Improved cognitive performance and mental fatigue following a multi-vitamin and mineral supplement with added guarana (Paullinia cupana). Appetite 2008, 50, 506-513. [CrossRef] [PubMed]

49. Kennedy, D.; Scholey, A.B. A glucose-caffeine'energy drink'ameliorates subjective and performance deficits during prolonged cognitive demand. Appetite 2004, 42, 331. [CrossRef] [PubMed]

50. Reay, J.L.; Kennedy, D.O.; Scholey, A.B. Single doses of panax ginseng (g115) reduce blood glucose levels and improve cognitive performance during sustained mental activity. J. Psychopharmacol. 2005, 19, 357-365. [CrossRef] [PubMed]

51. Reay, J.L.; Kennedy, D.O.; Scholey, A.B. Effects of panax ginseng, consumed with and without glucose, on blood glucose levels and cognitive performance during sustained'mentally demanding'tasks. J. Psychopharmacol. 2006, 20, 771. [CrossRef] [PubMed]

52. Scholey, A.B.; French, S.J.; Morris, P.J.; Kennedy, D.O.; Milne, A.L.; Haskell, C.F. Consumption of cocoa flavanols results in acute improvements in mood and cognitive performance during sustained mental effort. J. Psychopharmacol. 2010, 24, 1505-1514. [CrossRef] [PubMed]

53. Orhan, I.; Kartal, M.; Kan, Y.; Sener, B. Activity of essential oils and individual components against acetyl and butyrylcholinesterase. Z. Naturforsch. (C) 2008, 63, 547-553. [CrossRef]

54. Ashoor, A.; Nordman, J.C.; Veltri, D.; Yang, K.-H.S.; Al Kury, L.; Shuba, Y.; Mahgoub, M.; Howarth, F.C.; Sadek, B.; Shehu, A. Menthol binding and inhibition of $\alpha 7$-nicotinic acetylcholine receptors. PLoS ONE 2013, 8, e67674. [CrossRef] [PubMed]

55. Teichert, R.W.; Raghuraman, S.; Memon, T.; Cox, J.L.; Foulkes, T.; Rivier, J.E.; Olivera, B.M. Characterization of two neuronal subclasses through constellation pharmacology. Proc. Nat. Acad. Sci. USA 2012, 109, 12758-12763. [CrossRef] [PubMed]

(C) 2018 by the authors. Licensee MDPI, Basel, Switzerland. This article is an open access article distributed under the terms and conditions of the Creative Commons Attribution (CC BY) license (http://creativecommons.org/licenses/by/4.0/). 